\title{
Response of Hybrid Lowland Rice (Oryza sativa L.) Cultivar FARO44 to Salinity in Coastal Plain Sands of the Niger Delta, Nigeria
}

\author{
Achinike Emoghene, Elsie Ihuakwu Hamadina*, Andrew Efisue \\ Crop and Soil Science Department, Faculty of Agriculture, University of Port Harcourt, Port Harcourt, Nigeria
}

Email address:

eachinikes@yahoo.com (A. Emohene),elsieile@yahoo.com (E. I. Hamadina), efisue.andrew@uniport.edu.ng (A. Efisue)

To cite this article:

Achinike Emoghene, Elsie Ihuakwu Hamadina, Andrew Efisue. Response of Hybrid Lowland Rice (Oryza sativa L.) Cultivar FARO44 to Salinity in Coastal Plain Sands of the Niger Delta, Nigeria. Journal of Plant Sciences. Vol. 3, No. 2, 2015, pp. 106-110.

doi: $10.11648 /$ j.jps.20150302.20

\begin{abstract}
Salinity is veritable issue in coastal lowlands of Niger Delta, due to salt water intrusion, and can reduce yield of lowland rice. Hybrid lowland rice cultivar (particularly FARO44; SIPI) are currently distributed and cultivated across Nigerian agroecological zones but the specific effect of salinity on these hybrid rice varieties is not well defined. This study seeks to determine the effect of sodium chloride $(\mathrm{NaCl})$ on germination and seedling growth of FARO44 (SIPI). The study was a pot experiment, with 5 levels of sodium chloride $(\mathrm{NaCl})$ concentrations $\left(0,1.0,1.5,3.0\right.$, and $\left.5.0 \mathrm{dS} \mathrm{cm}^{-1}\right)$. The seeds took about 30 days to germinate in the control, as compared to other treatments. Germination was $42 \%$ in the control, $45 \%$ at $1.0 \mathrm{dS} \mathrm{cm}^{-1}$ and $34 \%$ at $5.0 \mathrm{dS} \mathrm{cm}^{-1}$. A visual assessment for salt injury showed that the Control plants had normal growth of leaves and at $5.0 \mathrm{dS} \mathrm{cm}^{-1} \mathrm{NaCl}$, there was nearly normal growth of leaves but the tips of the leaves were whitish and rolled. Vegetative growth studies showed that the height to the first leaf in the control was $4.45 \mathrm{~m}$ and the longest height to the first leave was recorded at $1.5 \mathrm{dS} \mathrm{cm}^{-1} \mathrm{NaCl}$. The tallest $(38.7 \mathrm{~cm})$ plants were observed at the $1.5 \mathrm{dS} \mathrm{cm}^{-1} \mathrm{NaCl}$ treatment but it was statistically similar with other treatment expect in the control which had the lowest plant height $(23.4 \mathrm{~cm})$. The highest number of leaves was recorded at $1.5 \mathrm{dS} \mathrm{cm}^{-1} \mathrm{NaCl}$ concentration, while lowest was recorded with $5.0 \mathrm{dS} \mathrm{cm}^{-1} \mathrm{NaCl}$. FARO44(SIPI) appears to tolerate $\mathrm{NaCl}$ of up to $1.5 \mathrm{dS} \mathrm{cm}^{-1}$.
\end{abstract}

Keywords: Tomato Hybrids, Heat Tolerance, Humid Tropics

\section{Introduction}

Rice (Oryza sativa L.) constitutes the principle food of about half of the world's population [1]. Among the cereals, rice production is only slightly below that of wheat. During 1961-1965, rice was grown on 124 million hectares in the world with an annual production of 253 million tonnes. In 1979 , the figures rose to 145 million hectares and 380 million tonnes, an increase of $16 \%$ in area and $50 \%$ in production This increase is strongly associated with the adoption of modern or improved cultural practices [2]. In Nigeria, rice is no longer a luxury food and has become a major source of calories for the urban poor, providing about 2,400 calories per person per day [3]. An adult Nigerian consumes about $24.8 \mathrm{~kg}$ of rice per year, representing $9 \%$ percent of annual calorie intake [4]. In the 1960s, Nigeria had the lowest per capita annual consumption of rice in the West African subregion with an annual average of $3 \mathrm{~kg}$. Since then, Nigeria's per capital consumption has grown significantly to 7.3 percent annum. Between 1974 and 1995 many programs were set up to boost rice production in Nigeria but these did not increase local production enough to surpass demand [5]. To improve the supply of rice to meet rising demand, the Nigerian Government now imports over 2 million tons of rice compared with 657,000 tons imported in the 1990s ([6], [7]). This intervention is certainly unsustainable. In view of the importance of rice to the socio-economy growth of Nigeria, the increasing demand for rice since mid-1970s [3] and the increasing world population, the need to increase rice availability through increased production and productivity is crucial.

Farmers in the Niger Delta region of Nigeria are currently encouraged to grow high yielding varieties such as FARO44 (SIPPI) so as to increase grain yield, Also, the Nigerian 
government current intervention on agriculture termed 'Agriculture Transformation Agenda' is encouraging the cultivation of more land area to lowland rice production and supporting the entire rice value chain. The seven hybrid varieties, which includes FARO44 (SIPPI), that are emphasized across the rice belt in Nigeria still have low grain yields ( $<2-4$ tons $\mathrm{ha}^{-1}$ for lowland rice).

Salinity is one of the major soil constraints limiting rain fed or irrigated rice yields in coastal areas and flood plains [8]. Lowland rice is grown in soils that remain inundated with water from the time of transplanting until harvesting. Lowland rice is either grown under a rainfed or artificial irrigation system, and its yield is much higher than that of upland rice [1]. However, soil salinity is one of the most serious problems of irrigated agriculture which drastically affect crop productivity throughout the world. Sodium is known to be taken up passively and transported within transpiring plants via the transportation stream, and accumulate in transpiring leaf blades ([9], [10]). Rice varieties suffer from excess uptake of sodium into photosynthetically active tissues, leading to reduced grain yields. However, earlier work showed that bulk stem tissues had higher sodium concentrations than leaf blades leading to the question whether the salt load of individual leaves is indicative of their transpiration history and thus accumulated water loss [8]. Irrigation water often has moderate sodium chloride levels but can carry high loads of Boron. Combined with low soil $\mathrm{pH}$, sodium and boron toxicity can occur under saline conditions, accompanied by secondary deficiencies of potasium and calcium. High salinity causes both hyper osmostic and ionic stress, which alters metabolic processes in plants leading to ionic imbalances, alterations of water potentials and specific ion toxicity ([11], [12]).

Unfortunately, the specific response of the recommended lowland rice varieties to salinity needs to be understood. Also in view of climate change issues and possible rise in salinity of coastal lands due to flooding [13], it is important to know the response of the hybrid lowland rice varieties to a broad range of salinity. Therefore, this study was designed to evaluate the effect of five (5) sodium chloride $(\mathrm{NaCl})$ salts concentration $(0,1.0,1.5,3.0,5.0 \mathrm{ds} / \mathrm{cm})$ on germination, seedling growth and nutrient uptake of the commonly cultivated hybrid lowland rice FARO 44 (SIPPI).

\section{Materials and Methods}

\subsection{Experimental Site and Soil Characteristics}

The experiment was conducted in a screen-house at the University of Port Harcourt, located in the humid tropical Niger Delta. The temperature and relative humidity within the sceenhouse during the study, averaged $23^{\circ} \mathrm{C}$ and $65 \%$ respectively (monitored using wireless weather station (Model BTHR 968). The soil used in this study was a sandy loam, with low base cations and fertility. The soil was characterized by low nitrogen and sulphate, but moderate phosphate and organic matter contents.

\subsection{Rice Variety Tested}

The rice cultivar used in this experiment was FARO 44(SIPPI) obtained from the African Rice Centre ITTA, Ibadan. FARO44 (SIPI) is an early maturing (100-115 days); lowland rice variety that is recommended for cultivation under different production systems including rain fed and irrigated lowland, and swamp/flood production.

\subsection{Experimental Design and Procedures}

The experimental design was Completely Randomized Design (CRD) consisting of five levels of sodium chloride 0 , $1.0,1.5,3.0$ and $5.0 \mathrm{dS} \mathrm{cm}^{-1}$ replicated 3 times. The salt concentrations were chosen based on knowledge of the general response of plants to salt levels ranging from 0 to $7.5 \mathrm{dS} \mathrm{cm}^{-1}$ as reported by Richard, 1954 [14]. The test concentrations were prepared using analytical grade sodium chloride (M\&B brand).

Table 1. Standard evaluation score (SES) of visual salt injury at seedling stage

\begin{tabular}{|c|c|c|}
\hline Plant Appearance & Tolerance Level & Score \\
\hline Normal growth, no leaf symptom & Highly tolerant & 1 \\
\hline Nearly normal growth but with whitish and rolled leaves or leaf tips & Tolerant & 3 \\
\hline Growth severely retarded most leaves rolled, only a few leaves are elongated & Moderately tolerant & 5 \\
\hline Complete ceasation of growth most leave dry, some plant dying & Susceptible & 7 \\
\hline Almost all plants dead or dying & Highly susceptible & 9 \\
\hline
\end{tabular}

Source: Gregorio et al., 1997

Seven rice seeds were planted into 10 -liter capacity plastic buckets, filled with $15 \mathrm{~kg}$ of surface soil $(0-15 \mathrm{~cm})$ collected within the study site, thinned to three seedlings per pot. Composite samples of the soil medium were collected for determination of soil physico-chemical characteristics. Each pot containing dry soil was irrigated with $1 \mathrm{~L}$ of one of the five treatment solutions and then the pots were allowed to stabilize for 4 days before planting. Seven rice seeds were planted in each pot in the month of June. After germination, plant number per pot was thinned to 3 stands per pots. At 6 weeks after planting, the rice seedling were visually assessed for visual salt injuries and scored for salt tolerance, using modified standard evaluation score (Table 1), as recommended [15]. The seedlings were also assessed for height to first node, plant height, number of leaves per plant and, length and width of leaves. The seedlings were then harvested, dried at $70{ }^{\circ} \mathrm{C}$ to constant weight, ground for chemical analysis. 


\subsection{Statistical Analysis of Data}

Data generated on germination and plant growth parameters were analyzed using one-way analysis of variance (no blocking) on Genstart Release 10.3DE (VSN International Ltd.). Leaf number data was transformed using square root transformation prior to data analysis. Mean separation was done using least square difference $\left(\mathrm{LSD}_{0.05}\right)$

\section{Results}

\subsection{Effect of NaCl Salinity on Germination}

On the average, it took about 30 days for the tomato seeds to germinate in the Control treatment, while seeds planted in the $\mathrm{NaCl}$ treated soils germinated earlier by at least 12 days $(\mathrm{P}<0.05)$. However, there were no significant $(\mathrm{P}<0.05)$ differences between the different levels of $\mathrm{NaCl}$ treatment in terms of duration to germination.

Table 2. Effects of salinity on germination of rice seeds

\begin{tabular}{|c|c|c|c|}
\hline \multirow{2}{*}{$\begin{array}{l}\text { Salinity Level } \\
\text { (dS cm-1) }\end{array}$} & \multicolumn{2}{|c|}{ Attributes of Germination } & \multirow[b]{2}{*}{ Duration } \\
\hline & $\%$ & Index & \\
\hline 0.0 & 42 & - & 29.6 \\
\hline 1.0 & 45 & 107 & 17.6 \\
\hline 1.5 & 42 & 100 & 17.5 \\
\hline 3.0 & 37 & 88 & 13.6 \\
\hline 5.0 & 34 & 80 & 17.2 \\
\hline $\operatorname{LSD}_{(0.05)}$ & - & - & 2.82 \\
\hline
\end{tabular}

The mean duration to germination was about 30 days while the duration from planting to germination was much shorter in the salt treatment as compare to the Control. At $1.0 \mathrm{ds} / \mathrm{cm}$ and $1.5 \mathrm{dS} \mathrm{cm}^{-1}$ as well as 5.0 , the duration occur (12 days) earliar than in the control while the shorter duration to germination was occured in $3.0 \mathrm{dS} \mathrm{cm}^{-1}$ which occured in 17 days earliar. At $3.0 \mathrm{dS} \mathrm{cm}^{-1}$ and $5.0 \mathrm{dS} \mathrm{cm}^{-1}$ salt concentrations, both the \% germination and germination index were reduced as compared to other treatments (Table 2).

\subsection{Effect of Salinity on Seedling Salinity Tolerance}

The physical examination of the seedlings show that the FARO44 is tolerant or moderately tolerant to salinity, as the seedlings under all treatments looked normal, and there were no observable effects of salinity. Seedlings subjected to 1.0 and $1.5 \mathrm{dS} \mathrm{cm}^{-1}$ salinity showed normal growths but the leaf tips were whitish, being more pronounced under $3.0 \mathrm{dS} \mathrm{cm}^{-1}$ or $5.0 \mathrm{dS} \mathrm{cm}^{-1}$ treatments.

\subsection{Growth Performance of FARO44 Seedlings}

The longest height to first leaf was observed at $1.0 \mathrm{dS} \mathrm{cm}^{-1}$ $\mathrm{NaCl}$ treatment and this was significantly $(\mathrm{P}<0.01)$ longer than those of the Control (Table 4), but not significantly $(\mathrm{P}<0.01)$ different than that of $1.5 \mathrm{dS} \mathrm{cm}^{-1}$ and $5.0 \mathrm{dS} \mathrm{cm}^{-1}$ $\mathrm{NaCl}$. The lowest height to the first leaves was observed under the Control $\left(0 \mathrm{dS} \mathrm{cm}^{-1}\right)$. Similarly, the $\mathrm{NaCl}$ treatments had significantly $(\mathrm{P}>0.05)$ taller plants than the Control, but only $1.0 \mathrm{dS} \mathrm{cm}^{-1}$ and $1.5 \mathrm{dS} \mathrm{cm}^{-1}$ treatments were significantly $(\mathrm{P}>0.05)$ different than the Control (Table 4).

Table 3. Visual salt injury at seedling stage

\begin{tabular}{|c|c|c|c|}
\hline Concentration, $\mathrm{dS} \mathrm{cm}^{-1}$ & Observation & Score & Tolerance \\
\hline 0 & Normal growth, no leaf symptom & 1 & - \\
\hline 1.0 & Nearly normal growth but leaf tips or few leaves whitish and rolled & 3 & Tolerant \\
\hline 1.5 & Nearly normal growth but leaf tips or few leaves whitish and rolled & 3 & Tolerant \\
\hline 3.0 & $\begin{array}{l}\text { In most plants, nearly normal growth was observed but leaf tips or few leaves were } \\
\text { whitish and rolled. In a few plants, most leaves were rolled }\end{array}$ & 4 & $\begin{array}{l}\text { Moderately } \\
\text { tolerant }\end{array}$ \\
\hline 5.0 & $\begin{array}{l}\text { In most plants, nearly normal growth was observed but leaf tips or few leaves were } \\
\text { whitish and rolled. In a few plants, most leaves were rolled. }\end{array}$ & 4 & $\begin{array}{l}\text { Moderately } \\
\text { tolerant }\end{array}$ \\
\hline
\end{tabular}

The highest number of leaves was recorded at $1.5 \mathrm{dS} \mathrm{cm}^{-1}$ $\mathrm{NaCl}$, while the lowest was recorded at salinity level of 5.0 $\mathrm{dS} \mathrm{cm}{ }^{-1} \mathrm{NaCl}$ (Table 4). Salinity treatments below $1.5 \mathrm{dS} \mathrm{cm}^{-}$ ${ }^{1}$ had the widest leaf width. The least leaf width was recorded under the Control treatment. There were significant differences in leaf length, with $1.0 \mathrm{dS} \mathrm{cm}^{-1} \mathrm{NaCl}$ treatment having the longest leaves. Treating the soil with $\mathrm{NaCl}$ at 3 . shortest leaf was recorded in pots receiving $3.0 \mathrm{dS} \mathrm{cm}^{-1} \mathrm{NaCl}$ treatment, but the lowest leaf length $(9.05 \mathrm{~cm})$ was recorded at $3.0 \mathrm{dS} \mathrm{cm}^{-1} \mathrm{Nacl}$ but was statistically similar to that of 0 and $5.0 \mathrm{dS} \mathrm{cm}^{-1}$, thus $1.0 \mathrm{dS} \mathrm{cm}^{-1}$ and $1.5 \mathrm{dS} \mathrm{cm}^{-1}$ salinity resulted in longer leaves, while 3.0 and $5.0 \mathrm{dS} \mathrm{cm}^{-1}$ was not different, when compared to the control.

Table 4. The effect of salinity on plant growth at 6WAT

\begin{tabular}{|c|c|c|c|c|c|}
\hline \multirow{2}{*}{ Salinity Levels ( $\left.\mathrm{dS} \mathrm{cm}^{-1}\right)$} & \multirow{2}{*}{ Height to 1st Node (cm) } & \multirow{2}{*}{ Plant height (cm) } & \multicolumn{3}{|c|}{ - Leaf Attributes --- } \\
\hline & & & Number & Width (cm) & Length (cm) \\
\hline 0.0 & 4.45 & 23.4 & 1.91 & 0.25 & 12.2 \\
\hline 1.0 & 7.3 & 38.5 & 1.87 & 0.33 & 16.7 \\
\hline 1.5 & 6.08 & 38.7 & 2.00 & 0.38 & 16.4 \\
\hline 3.0 & 5.57 & 24.1 & 1.72 & 0.29 & 9.05 \\
\hline 5.0 & 6.25 & 29.9 & 1.67 & 0.29 & 12.9 \\
\hline $\operatorname{LSD}(0.05)$ & 1.67 & 11.8 & 0.231 & 0.052 & 4.62 \\
\hline
\end{tabular}


The highest number of leaves was recorded at $1.5 \mathrm{dS} \mathrm{cm}^{-1}$ $\mathrm{NaCl}$, while the lowest was recorded at salinity level of 5.0 $\mathrm{dS} \mathrm{cm}{ }^{-1} \mathrm{NaCl}$ (Table 4). Salinity treatments below $1.5 \mathrm{dS} \mathrm{cm}^{-}$ ${ }^{1}$ had the widest leaf width. The least leaf width was recorded under the Control treatment. There were significant $(\mathrm{P}<0.05)$ differences in leaf length, with $1.0 \mathrm{dS} \mathrm{cm}^{-1} \mathrm{NaCl}$ treatment having the longest leaves. Treating the soil with $\mathrm{NaCl}$ at 3 . shortest leaf was recorded in pots receiving $3.0 \mathrm{dS} \mathrm{cm}^{-1} \mathrm{NaCl}$ treatment, but the lowest leaf length $(9.05 \mathrm{~cm})$ was recorded at $3.0 \mathrm{dS} \mathrm{cm}^{-1} \mathrm{Nacl}$ but was statistically similar to that of $0 \mathrm{dS} \mathrm{cm}^{-1}$ and $5.0 \mathrm{dS} \mathrm{cm}^{-1}$, thus $1.0 \mathrm{dS} \mathrm{cm}^{-1}$ and $1.5 \mathrm{dS} \mathrm{cm}^{-1}$ were not significantly $(\mathrm{P}<0.05)$ different than the Control, $3.0 \mathrm{dS} \mathrm{cm}^{-1}$ and $5.0 \mathrm{dS} \mathrm{cm}^{-1} \mathrm{NaCl}$ significantly $(\mathrm{P}<0.05)$ lower when compared to the Control.

Table 5. Salinity effects on $R D W$

\begin{tabular}{lll}
\hline Salinity $\left(\mathbf{d S ~ c m}^{-\mathbf{1}}\right)$ & $\mathbf{R D W}_{\text {total }}(\mathbf{6}$ WAT $)$ & $\mathbf{R D W}_{\text {panicle }}(\mathbf{1 4} \mathbf{W A T})$ \\
\hline 0 & - & - \\
1.0 & 100 & 143 \\
1.5 & 141 & 230 \\
3.0 & 100 & 113 \\
5.0 & 88 & 83 \\
\hline
\end{tabular}

\subsection{Effects of Salinity on Relative Dry Weights}

The percentage relative dry total weight $\left(\mathrm{RDW}_{\text {total }}\right)$ at 6WAT and the relative panicle dry weight $\left(\mathrm{RDW}_{\text {panicle }}\right)$ at 14 WAT are shown in Table 5. The Control and $1.0 \mathrm{dS} \mathrm{cm}^{-1}$ had RDW of $100 \%$, and the highest was under $1.5 \mathrm{dS} \mathrm{cm}^{-1}$ treatment, beyond which the effect declined. Similarly, the relative panicle dry matter was also highest under the $1.5 \mathrm{dS} \mathrm{cm}^{-1}$ treatment (Table 5). Salinity above $1.5 \mathrm{dS} \mathrm{cm}^{-1}$, both the $\mathrm{RDW}_{\text {total }}$ and $\mathrm{RDW}_{\text {panicle }}$ decreased significantly.

\section{Discussion}

The different salinity levels significantly $(\mathrm{P}<0.05)$ affected the percentage seed germination of FARO44 (SIPPI). The results show that germination percentage decreased with the increasing salinity levels, albeit not linearly. Similar observations in several rice varieties have been reported [16, 17]. This suggest that FARO44 seedlings would need nurturing in nurseries before transplanting in the field.

Based on the modified tolerance evaluation score, FARO44 rice seedlings can be said to be tolerant to salinity levels up to $1.5 \mathrm{dS} \mathrm{cm}^{-1}$, and moderately tolerant to salinity levels of 3.0 and $5.0 \mathrm{dS} \mathrm{cm}^{-1}$. This findings agree with the reports of salinity tolerance of seedlings of some rice varieties [18], and also suggest that FARO44 has the potential to adapt well to the salinity conditions of the coastal Niger Delta areas. Low salinity levels of $1.0 \mathrm{dS} \mathrm{cm}^{-1}$ and $1.5 \mathrm{dS} \mathrm{cm}^{-1}$, there was a general increase, while higher salinity treatments $(3.0 \mathrm{dS} \mathrm{cm}$ 1 and $\left.5.0 \mathrm{dS} \mathrm{cm}^{-1}\right)$ had decreased the values of growth parameters observed (i.e., length to first node, plant height, and leaf dimensions),

Higher salinity levels affected relative dry weights (\%RDW) of FARO44 seedlings (at 6 WAT). At salinity level of $1.0 \mathrm{dS} \mathrm{cm}-1$, dry weight of the seedling was not affected (RDW 100\%), while at salinity level of $1.5 \mathrm{dS} \mathrm{cm}-1$, seedling dry weight increased by $41 \%$ However at $3 \mathrm{dS} \mathrm{cm}-1$ and $5 \mathrm{dS} \mathrm{cm}-1$ salinity levels, there was a significant decline in dry weight $(\mathrm{P}<0.05)$. The panicle dry matter (at 14 WAT) followed the same trend with total dry weight at 6 WAT.

The data presented suggest a decline in dry matter content with high salinity levels. Although this study did not look at the mechanism of the effect of salinity on plants, Islam et al. (2007) showed that total chlorophyll content decreased with increased level of salinity. In a separate study, it was reported that a reduction of chlorophyll content resulted in reduced seedling dry weight [18]. The effects of high salinity on plants results in exosmosis, a phenomenon, which in part, alters the plants physiological processes, including uptake of nutrients and water [19]. Zeng and Shannon, 2000 [20] reported a reduction in length to first node due to increase in salinity.

\section{Conclusion}

This study was designed to evaluate the effect of $\mathrm{NaCl}$ on seedling growth and nutrient uptake of hybrid lowland rice variety FARO44 (SIPI). The result obtained showed that there was a delay in duration to germination of the seeds in the Control, but not with other treatments. Visual observations for seedlings show FARO44 is tolerant to moderately tolerant of salinity at low levels of $1.5 \mathrm{dS} \mathrm{cm}^{-1}$.

\section{References}

[1] Remison, U. 2005. Arable and Vegetable Crops of the Tropics. Gift Prints Associates. pp19-30

[2] Domnic, J. U. 2005. Crop Production Techniques in the Tropics. Concept Publication Limited, Lagos, Nigeria.

[3] Imolehin, E.D. and A.C. Wada. 2000. Meeting the rice production and consumption demands of Nigeria with improved technologies. Int. Rice Com. Newsl. FAO http://www.fao.org/docrep/x7164t/x7164t04.htm\#P0_0

[4] IRRI, 2001. Annual Report,International Rice Research Institute, IRRI, Los Barros, Phillipines.

[5] Singh, B.N., Fagade, S., Ukwungwu, M.N., Williarn, C., Jagtap, S.S., Oladimeji, O., Effisue, A. and Okhidievbie, O. 1997. Rice growing environments and biophysical constraints in different agroecological zones of Nigeria. Met. J., 2(1): 35-44.

[6] IRRI. 1991. World Rice Statistics, p. 34-42.

[7] IRRI. 1995. World Rice Statistics, p. 34-42

[8] Asch, F., Wimmer, M. A. Keshav, P. D.and Udays, D. 2003. Boron Distribution Shows Sodium Distribution in Rice Leaves to be Independent of Transpiration. Conf. Int, Agr. Res. Devel. pp124

[9] Yeo, A R., S. M. Caoorn and T. J. Flower. 1985. The Effect of Salinity Upon Photosynthesis in Rice (Oryza sativa L.): Gas Exchange by Individual Leaves in Relation to their Salt Content. J. Exp. Agr. 36:1240-1248 
[10] Shelp, B. J., E. Marentes. A. M. Kitheka, and P. Vivekanandan. 1995. Boron mobility in plants. Physiol. Plant 94: 356 - 361

[11] Munns, R. 2002. Comparative physiology of salt and water stress. Plant Cell Environ. 25: 239 - 250

[12] Tester M, and Davenport, R. 2003. $\mathrm{Na}^{+}$tolerance and transport in higher plants. Ann. Bot. 91: 503 - 527

[13] Sembring, H. and Gani. A. 2007. Adaptability of Rice on Tsunami Affected Soil. Training Workshop Soil Management for Rebuilding Agriculture in Tsunami Affected Areas in Nangrovve Acch Darussalam Province, Banda Acch. pp13-16

[14] Richard LA. 1954. Diagnosis and improvement of saline and alkali soils. Agriculture Handbook No. 60. United States Department of Agriculture. Washington, USA: Government Printing Office.

[15] Gregorio, G. B., D. Senadhira and R. D. Mendoza. 2002. Progress in Breeding for Salinity Tolerance and Associated Abiotic Stresses in Rice Field Crop Res. 76 (2-3); 91 - 101
[16] Hossain, M. S. 2004. Effect of Salinity on Germination, Growth Biochemical Attributes and Yield of Rice Nutrients. M. Sc. Thesis. Bangladesh Agricultural University Mymensingh.

[17] Khan, M.S.A, Hamid, A. and Karim. M.A. 1997.. Effect of Sodium Chloride on Germination and Seedling Characters of Different Types of Rice (Oryza sativa L). J. Agr. Crop Sci, 179: $163-169$.

[18] Islam, M. M and Karim, M.A.. 2011. Evaluation of rice (Oryza sativa L.) genotypes at germination and early seedling stage for their tolerance to salinity. Agriculturist 8(2):57-65

[19] Dagar, I.C. 1996. Rehabilitation of coastal saline lands by planting suitable species. I. Ind. Soc. Coast. Agr. Res. 14 (1 2): 185-194

[20] Zeng L and M. C., Shannon. 2000. Salinty effects on seedling growth and yield yomponents of rice. Crop Sci. 40: 996 - 1003 